\title{
LATS1 Gene
}

National Cancer Institute

\section{Source}

National Cancer Institute. LATS1 Gene. NCI Thesaurus. Code C24541.

This gene is involved in the maintenance of genomic stability. 